\title{
外傷性寛骨且骨折の検討
}

\author{
川添泰 臣* 本木下 亮 ${ }^{*}$ 川畑 英 之* \\ 有 島 善 也** 石 堂 康 弘*** 小宮 節 郎****
}

\section{Treatment of Traumatic Acetabular Fracture}

\author{
Yasuomi Kawasoe*, Ryo Motokishita*, Hideyuki Kawabata*, \\ Yoshiya Arishima**, Yasuhiro Ishidou***, \\ and Setsuro Komiya***
}

\begin{abstract}
外傷性寛骨臼骨折を生じた 4 例を経験した。 H 20.3 月から H 21. 1 月までに当科にて経験した同骨折 4 例（男性 3 例，女性 1 例），年齢 34〜 72 歳を対象とした。骨折分類は Judet-Letournel 分類を用いた. 後壁骨折 2 例（1例に骨頭骨折を合併），後壁骨折＋横骨折 1 例，両柱骨折 1 例であった。初診時 3 例に 後方脱臼を認め，徒手整復を施行した．１例は保存治療を行い，3 例に手術治療を施行した。術後 JOA score は 78〜 91 (平均 85.0) であり, 経過観察期間での大腿骨頭壊死や変形性関節症の出現は認められて いない，寛骨臼骨折の多くは高エネルギー外傷の結果生じ，長期臥床を強いられる。早期社会復帰には手 術治療による解剖学的に良好な整復位での強固な固定を行い, 受傷後早期からのリハビリ訓練が重要と考 える. また将来的に変形性関節症の発症を予防するためにも手術治療は有用と考える.
\end{abstract}

Four cases of traumatic acetabular fracture were treated during 2008 to 2009. They included three male and one female patients with a mean age of 47 years (range; 37 to 74 years). The mean period of follow-up was 12 months. The fracture types were classified by Judet-Letournel. There were two posterior walls, one transverse/posterior wall, and one both columns. Three patients had dislocation of the hip at the time of injury, and closed reduction was performed within six hours after injury. One patient was treated by nonsurgical procedure and three by open reduction and internal fixation. The mean surgical time was 2.4 and the mean blood loss was 460 cc. The overall clinical outcome was rated as excellent in three (75\%) and good in one (25\%). Acetabular fracture caused by high energy trauma may have serious complications (vascular injury, post-traumatic osteoarthritis). Anatomical reduction, stable fixation, and early rehabilitation are important to successfully treat and reduce serious complications.

Key words：trauma (外傷), acetabulum（寛骨臼）, fracture（骨折）

\section{は じめ に}

寛骨臼骨折の多くは高エネルギー外傷の結果生じ， 特に若壮年に多くみられる，そのため，早期合併症に よる全身状態の悪化の夕ならず，晚期合併症として大 腿骨頭壊死や変形性股関節症の発生が問題となり，受 傷早期より適切な治療が必要と考えられる. 今回, 当
科において手術及び，保存治療を行つた外傷性寛骨臼 骨折の治療成績について検討したので文献的考察を加 え報告する.

対象

症例は 2007 年 1 月から 2009 年 1 月の 2 年間に当院 を受診し加療を行つた 4 症例 4 関節である. 男性 3 例,

\footnotetext{
* 県立大島病院整形外科 Department of Orthopaedic Surgery, Kagoshima Prefectural Oshima Hospital, Kagoshima, Japan

** 鹿児島赤十字病院整形外科 Department of Orthopaedic Surgery, Kagoshima Red Cross Hospital, Kagoshima, Japan

*** 鹿児島大学大学院医療関節材料開発講座 Department of Medical Joint Materials, Kagoshima Graduate School of Medical and Dental Sciences, Kagoshima, Japan

**** 鹿児島大学大学院医歯学総合研究科先進治療科学専攻運動機能修復学講座整形外科学 Department of Orthopaedic Surgery, Kagoshima Graduate School of Medical and Dental Sciences, Kagoshima, Japan
} 
女性 1 例であつた。受傷時年齢は 34〜 72 歳（平均 47 歳)。受傷原因は, 単車事故 2 例, 転落 1 例, 転倒 1 例であった. 単車事故 2 例と転倒 1 例の 3 例に後方脱 臼を認めた。術後経過観察期間は 6 ケ月から 2 年（平 均 12 ケ月）であった.

今回，寛骨臼骨折の分類には Judet-Letournel 分 類を用いた ${ }^{1)}$. 後壁骨折 2 例（1例に骨頭骨折を合併）， 後壁骨折＋横骨折 1 例，両柱骨折 1 例であった。初診 時に脱臼を認めた 3 例は受傷後 6 時間以内に徒手整復 を行い, 1 週間以内に手術治療を行った.

$$
\text { 結果 }
$$

機能判定は日本整形外科学会股関節機能判定基準 （以下 JOA score）を用いた。術後 JOA score は

表 1 治療結果

\begin{tabular}{lccccc}
\hline \hline 症例 & 経過観察期間 & 手術 & JOA score & 大腿骨頭壊死 & OA \\
\hline 34 歳 女 & 6 ケ月 & $(+)$ & 91 & $(-)$ & $(-)$ \\
36 歳 男 & 24 ケ月 & $(+)$ & 86 & $(-)$ & $(-)$ \\
46 歳 男 & 12 ケ月 & $(+)$ & 85 & $(-)$ & $(-)$ \\
72 歳 男 & 10 ケ月 & $(-)$ & 78 & $(-)$ & $(-)$ \\
\hline 術後 JOA & score は & $78 \sim 91$ 点 & (平均 85 点) & であった. 経 \\
過観察期間での大腿骨頭壊死や関節症の出現はなかった
\end{tabular}

78〜91 点（平均 85.0 点）と満足すべき結果が得られ た. 経過観察期間での大腿骨頭壊死や変形性関節症の 出現は無かった（表 1).

$$
\text { 症例 }
$$

症例 1 (図 1).34 歳女性. Judet-Letournel 分類 は simple fracture, 後壁骨折であった. Thompson \& Epstein TypeIIIの後方脱臼を認めたため, 受傷後 6 時間以内に非観血的脱臼整復を施行した。手術まで の待機期間は介達牽引を施行し，受傷後 7 日に観血的 骨接合術を施行した。手術は Kocher-Langenbeck 法 （以下 K-L 法）により後方を展開し，後壁を screw 及 び bending した plateにて固定した。術後 4 週にて LLB 装具装着下に部分荷重を開始し, 術後 8 週目よ り全荷重とした。術後 6 ケ月時点での臨床評価は JOA score 91 点と良好である.

症例 2（図 2).46 歳男性. Judet-Letournel 分類 は simple fracture, 後壁骨折に骨頭骨折を合併して いた. Thompson \& Epstein TypeVの後方脱臼を 認めたため，初診時に非観血的脱臼整復術を施行．手 術までの待機期間は介達牽引を施行した。術後 17 日 目に観血的骨接合術を施行した. 手術は K-L 法にて
初診時 X-p

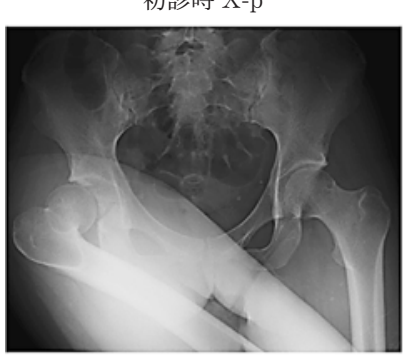

初診時股関節の後方脱臼を認めた.
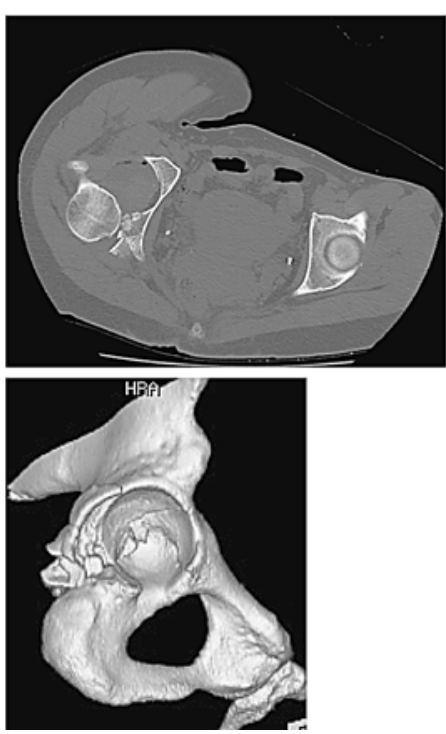

図 1 症例 $1: 34$ 歳女性 simple fracture; 後壁骨折
術後 X-p

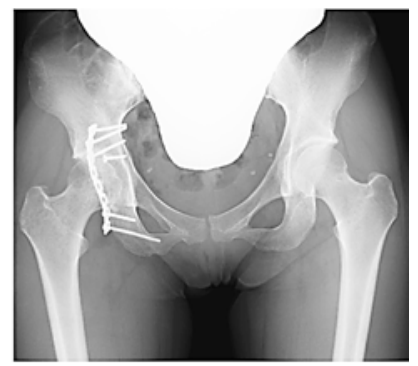

K-L 法により後方を展開, 後 壁を screw 及び bending した plate で固定. 


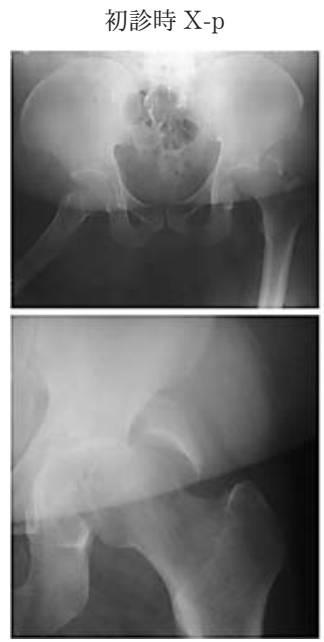

初診時股関節の後方脱臼 を認めた. Pipkin Type 4 の骨頭骨折を認めた.
初診時 $\mathrm{CT}$
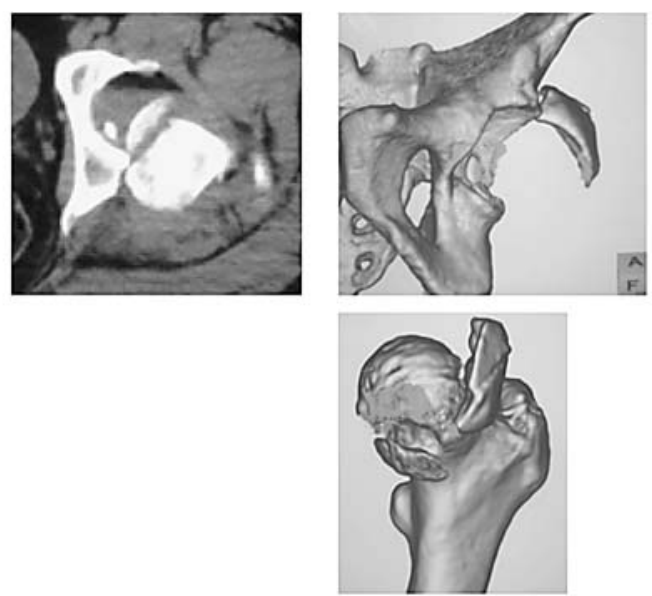

図 2 症例 2:46 歳男性 simple fracture ; 後壁骨折（骨頭骨折合併）
術後 X-p

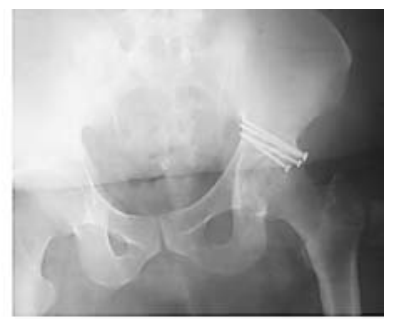

K-L 法にて展開，大転子を骨 切り反転し, 前方と後方を展開 した。 大腿骨頭は PLLA ピン にて固定, 後壁は CCS にて固 定した.
皮切を行い, 大転子を骨切り反転し前方と後方を展開 した。 大腿骨頭はポリ-L-乳酸（以下 PLLA）ピンに て固定，後壁は中空海綿骨スクリューにて固定した. 反転した大転子はPLLA スクリューにて固定した. 術後 4 週にて部分荷重を開始し, 術後 8 週で全荷重と した. 術後 12 ヶ月で JOA 85 点である.

$$
\text { 考察 }
$$

寛骨臼骨折は高エネルギー外傷に伴うことが多く， 多発外傷となりやすい, そのため, 初診時の全身評価 が重要となる. 致命的な合併症や大量出血により血行 動態が安定しない場合は早急な開腹手術や血管造影検 査，塞栓術などを施行すべきである，術前の骨折評価 として, 単純 X 線検査（前後像, 45 度両斜位）や, CT による評価が重要である．特に CT は複雑な寛骨 臼骨折の分類評価や，骨折片の大きさ，関節内骨片 の有無, marginal impactionの程度, 仙骨や仙腸関 節の骨折などの把握に有用である。転位のない骨折に は MRI が有用である。現在は 1964 年に Judetと Letournel が発表した分類が汎用され，これにより骨 折型に応じた手術侵入法が選択可能となった。手術時 期については様々な報告があるが受傷後 7 日以内が望 ましく，14 日を経過すると整復が困難となる報告 ${ }^{2)}$ が 多い. 股関節脱臼を伴う症例は大腿骨頭への血流障害
を改善するために, 受傷後 6 時間以内の脱臼整復が必 要である. 手術治療の適応は各症例の状態によるが, 佐々木らは，1）転位が $2 \mathrm{~mm}$ 以上 2）荷重部での適 合性が不良 3）roof arc angle が $45^{\circ}$ 以内 4）関節内 骨片が存在する場合, と報告している ${ }^{6)}$. われわれも, 今回の症例はこの適応に準じて治療法を決定した. 手 術治療のポイントとして澤口らは (1)画像診断（骨盤 3R，CT）にて骨折状態を正確に把握する. (2)骨折型, 転位に応じた適切なアプローチを選択する。(3)解剖学 的位置へ完全整復を目指す。と述べている7). また， 佐々木らは，許容される関節内の転位は $2 \mathrm{~mm}$ 以内 と述べている．いずれも変形性関節症の発症を防ぐた めには解剖的位置への完全整復を強調している ${ }^{334}$. 術 後合併症として 1）早期合併症と 2）晚期合併症にわ けられ，早期合併症には死亡, 感染, 神経損傷などが 挙げられる. 死亡は $0-2.5 \%$ と報告され, 肺塞栓症が 最も多い ${ }^{6)}$ 。また，寛骨臼骨折において術前の坐骨神 経損傷の合併は $12-25 \%$ と報告されている ${ }^{6)}$. 手術後 の医原性損傷は 2-6\%の報告がある。晚期合併症に は異所性骨化や大腿骨頭壊死症，外傷後変形性関節症 が見られる。 とくに外傷後変形性関節症は最も多い合 併症であり，整復不良による関節軟骨の不整が原因と なることがほとんどである ${ }^{36)}$. THA や固定術などの 二期的な手術が必要とする場合があるが, 変形後の 
THA の成績は不良との報告が多( ${ }^{335)}$ ，比較的まれな 疾患であるが，十分な術前計画と手術手技が求められ るものと考えられる.また, 2 年以上の経過観察を行 い, 大腿骨頭壊死や変形性関節症などの合併症に留意 すべきである.

$$
\text { ま と め }
$$

外傷性寬骨且骨折に対し，受傷早期に良好な整復位 で固定を行い，リハビリを開始することで良好な治療 成績が得られた。経過観察期間内では大腿骨頭壊死や 変形性股関節症の発症はなかったが, 引き続き経過観 察が必要と考える.

\section{参 考 文 献}

1) Judet, R., et al.: Fractures of the acetabulum: Classification and surgical approaches for open reduction: A preliminary report. J. Bone Joint Surg. Am., 46 : 1615-1646, 1964.

2）小久保安朗ら：寛骨臼骨折における観血的治療の問題 点と治療戦略. 中部整災誌, $50(2): 289-290,2007$.

3) Matta, J. M.: Fractures of the acetabulum: accuracy of reduction and clinical results in patients managed operatively within three weeks after the injury. J. Bone Joint Surg. Am., 78(11) : 1632-1645, 1996.

4) Mayo, K. A.: Open reduction and internal fixation of fractures of the acetabulum. Results in 163 fractures. Clin. Orthop. Relat. Res., $305:$ 31-37, 1994.

5）宮崎正志，高木一広：外傷性股関節脱臼骨折の検討. 整外と災外, 53(2)：259-264, 2004.

6）佐々木幹人ら：寛骨臼骨折の治療成績と変形性股関節 症の発生要因に関する検討. 北海道整災外会誌，43(1)： 1-4, 2001.

7）澤口 毅ら：寞骨臼骨折の診断と治療一複合骨折一. MB Orthop., 17(11) : 36-43, 2004. 